\title{
PROSES BERPIKIR MATEMATIS SISWA DALAM MENYELESAIKAN SOAL PISA KATEGORI HOTS DAN SCAFFOLDINGNYA
}

\author{
Maya Firdaustita Hawai \\ Pendidikan Matematika, FMIPA, Universitas Negeri Surabaya, e-mail: Maya.17030174014@mhs.unesa.ac.id
}

\section{Ika Kurniasari}

Pendidikan Matematika, FMIPA, Universitas Negeri Surabaya, e-mail: Ikakurniasari@unesa.ac.id

\begin{abstract}
Abstrak
Penelitian ini bertujuan untuk mendeskripsikan proses berpikir matematis siswa dalam menyelesaikan soal PISA kategori HOTS beserta scaffoldingnya. Proses berpikir matematis siswa ditinjau dari fase berpikir matematis yang dikembangkan oleh Mason, dkk. Pemberian scaffolding berdasarkan level scaffolding Anghileri. Jenis penelitian ini adalah deskriptif kualitatif. Subjek penelitian ini adalah 3 siswa kelas IX yang terdiri dari satu siswa berkemampuan matematika tinggi, satu siswa berkemampuan matematika sedang dan satu siswa berkemampuan matematika rendah. Subjek tersebut dipilih dari 31 siswa kelas IX SMP di Sidoarjo yang diberikan tes kemampuan matematika (TKM). Selanjutnya subjek terpilih diberi tes yang terdiri dari 3 soal PISA kategori HOTS dan dilakukan wawancara serta pemberian scaffolding. Pengambilan data ini dilakukan secara offline. Scaffolding diberikan ketika siswa mengalami stuck pada proses berpikir matematisnya. Hasil penelitian menunjukan: (1) Proses berpikir matematis subjek berkemampuan tinggi dalam menyelesaikan soal PISA HOTS level 5 dimulai dengan fase entry, dengan memenuhi indikator know, want, dan introduce. Dilanjutkan dengan fase attack dengan memenuhi aspek try, maybe, dan why. Kemudian dilanjutkan dengan fase review dengan memenuhi aspek check, reflect, dan extand. Proses berpikir matematis siswa berkemampuan matematika tinggi dalam menyelesaikan soal PISA HOTS level 6 dimulai dengan fase entry dengan melalui aspek know, want, dan introduce, dilanjutkan dengan fase attack dengan melalui aspek try dan maybe kemudian fase review dengan memenuhi aspek check, reflect, dan extand dan berulang dengan fase attack. (2) Dalam menyelesaikan soal PISA HOTS proses berpikir matematis subjek berkemampuan sedang dimulai dengan fase entry melalui aspek know, want, dan introduce, dilanjutkan dengan fase attack dengan melalui aspek try, maybe, dan why. (3) Proses berpikir matematis siswa berkemampuan matematika rendah dalam menyelesaikan soal PISA HOTS dimulai pada fase entry dengan memenuhi aspek know dan want. Kemudian dilanjutkan dengan memasuksi fase attack, namun hanya memenuhi aspek try. (4) Subjek berkemampuan matematika tinggi membutuhkan sedikit bantuan dalam menyelesaikan soal PISA HOTS level 6 pada fase attack. (5) Subjek berkemampuan matematika sedang membutuhkan scaffolding pada fase attack dan review. (6) Subjek berkemampuan matematika rendah membutuhkan scaffolding pada fase entry, attack dan review. (7) Setelah pemberian scaffolding, subjek berkemampuan tinggi, sedang maupun rendah memenuhi semua fase berpikir matematis. Sehingga subjek dapat menyelesaikan soal PISA kategori HOTS dengan benar.
\end{abstract}

Kata kunci: berpikir matematis, HOTS, kemampuan matematika, PISA, scaffolding.

\begin{abstract}
This study aims to describe the mathematical thinking process of students in solving PISA questions in HOTS category and scaffolding. The student's mathematical thinking process is reviewed from the mathematical thinking phase developed by Mason et al. Administration of scaffolding based on Anghileri's scaffolding level. This type of research is descriptive qualitative. The subjects of this study were 3 grade IX students consisting of one high mathematics ability student, one medium mathematics ability student, and one low mathematics ability student. The subjects were selected from 31 students of grade IX SMP in Sidoarjo who were given the Mathematical Ability Test (TKM). Furthermore, the selected subjects were given a test consisting of 3 PISA questions in the HOTS category and conducted interviews and provided scaffolding. This data collection was carried out offline. Scaffolding is given when students got stuck in their mathematical thinking prosess. The results showed: (1) The mathematical thinking process of highly skilled subjects in solving PISA HOTS level 5 questions began with the entry phase, by fulfilling the know, want, and introduce indicators. Followed by the attack phase by fulfilling the try, maybe, and why aspects. The, review phase by fulfilling the check, reflect, and extand aspects. The mathematical thinking process of students with high mathematical abilities in solving PISA HOTS level 6 questions begins with the entry phase by going through the know, want, and introduce aspects, followed by the attack phase by going through the try and maybe aspects then the review phase by fulfilling the check, reflect, and extand aspects
\end{abstract}


and repeated with the attack phase. (2) In solving PISA HOTS questions, the mathematical thinking process of a medium skilled subject begins with the entry phase through the know, want, and introduce aspects, followed by the attack phase through the try, maybe, and why aspects. (3) The mathematical thinking process of students with low mathematical abilities in solving PISA HOTS questions begins with the entry phase by fulfilling the know and want aspects. Then proceed by entering the attack phase, but only fulfilling the try aspect. (4) Subjects with high math abilities needed a little help in solving PISA HOTS level 6 questions in the attack phase. (5) Subjects with mathematical required scaffolding in the attack and review phase. (6) Subjects with low math ability required scaffolding in the entry, attack and review phases. (7) After scaffolding, high, medium, and low-skilled students fulfill all stages of mathematical thinking and solve the HOTS category PISA questions correctly.

Keywords: Mathematical thinking, HOTS, mathematical abilities, PISA, scaffolding.

\section{PENDAHULUAN}

Berpikir matematis merupakan salah satu tujuan dasar yang harus ditekankan dalam pembelajaran matematika (Tasdan, dkk., 2015). Berpikir matematis dapat mendukung sains, teknologi, dan ekonomi. Oleh karena itu, kemampuan berpikir matematis sangat diperlukan untuk menyelesaikan masalah matematika. Menggunakan kemampuan berpikir matematis dalam menyelesaikan masalah merupakan tujuan yang harus dicapai dalam pembelajaran matematika di sekolah. Banyak penelitian yang membahas tentang berpikir matematis siswa, misalkan Kesumawati (2014) dan Astriyani (2019).

Berdasarkan tujuan dasar tersebut, maka berpikir matematis seharusnya selalu melandasi kegiatan pembelajaran matematika. Menurut Mason, dkk. (2010) proses berpikir matematis adalah proses yang dinamis. Proses ini dapat memperluas dan memperdalam pemahaman matematika. Proses tersebut meliputi (1) proses pengkhususan yaitu spesialisasi seperti mengidentifikasi kasus-kasus khusus atau beberapa contoh, (2) proses perampatan yaitu generalisasi seperti memfokuskan pada contoh-contoh yang lebih banyak, menemukan pola dan hubungan, (3) proses penebakan yaitu membuat tebakan-tebakan atau dugaan tentang masalah yang dihadapi, (4) proses peyakinan yaitu membangun keyakinan terhadap pemahaman yang telah didapat, membuat dan mengomunikasikan alasan terhadap sesuatu.

Yani, dkk. (2016) menyatakan bahwa proses berpikir dalam matematika merupakan suatu kegiatan mental. Kegiatan ini terjadi dalam otak manusia. Proses berpikir terjadi ketika siswa menyelesaikan sebuah masalah. Lebih lanjut Mason, dkk. (2010) memposisikan proses berpikir matematis sebagai sebuah kegiatan prosedural yang memiliki 3 fase.

Fase yang pertama adalah fase masuk (entry). Fase masuk (entry) dilakukan untuk memahami suatu pertanyaan yaitu dimulai ketika pertama kali mengahadapi pertanyaan dan berakhir ketika telah memulai untuk mencoba memecahkannya. Terdapat tiga aspek pada fase entry yaitu aspek know, want dan introduce. Fase yang kedua adalah fase menyelesaikan (attack). Fase menyelesaikan (attack) dilakukan dengan cara mengambil beberapa rencana penyelesaian ataupun membuat dugaan penyelesaian yang dapat digunakan untuk menyelesaikan masalah dan merumuskan serta mencoba recana tersebut. Pada fase ini ini terdapat istilah stuck dan aha!. Stuck maksudnya siswa mengalami kendala saat berpikir atau siswa tidak dapat menyelesaikan soal. Aha! Ialah saat siswa menemukan ide untuk melanjutkan penyelesaian soal. Fase attack mempunyai tiga aspek yaitu try, why, dan maybe. Fase ketiga adalah fase meninjau ulang (review). Fase review seringkali dilakukan setelah mendapatkan solusi dari permasalahan. Fase review berguna untuk merefleksi fase-fase sebelumnya. Proses ini biasanya berlangsung saat siswa menyelesaikan soal-soal matematika yang tidak rutin

Soal matematika yang tidak rutin terdapat pada model soal PISA. Soal PISA adalah soal yang digunakan oleh Organitation for Economic Cooperation and Development (OECD) untuk mengetahui kemampuan berpikir siswa pada usia 15 tahun. Studi ini telah diikuti oleh beberapa negara dan Indonesia adalah salah satunya. (Setiawan, dkk., 2014).

Saol PISA terdiri dari enam level, yaitu level 1 , level 2, level 3, level 4, level 5 dan level 6 (OECD, 2015). Level tersebut menunjukkan tingkatan kemampuan matematika menurut PISA. Dengan membandingan karakteristik level PISA dengan level kognitif revised Bloom's Taxonomy, Setiawan, dkk., (2014) menggolongkan soal PISA menjadi dua kategori yaitu kategori berpikir tingkat rendah pada level 1-3 dan berpikir tingkat tinggi pada level 4-6.

Setiawan, dkk. menyatakan bahwa berpikir tingkat tinggi (higher order thinking) meliputi kemampuan menganalisis, menilai dan mencipta. Kemampuan tersebut merupakan bagian dari level kognitif Taksoonomi Bloom. Kemampuan menganalisis (C4), menilai (C5) dan mencipta (C6). Terdapat beberapa cara untuk mengukur kemampuan berpikir tingkat tinggi siswa. Salah satunya adalah dengan cara memberikan soal-soal yang non algorithmic, soal-soal tersebut harus mengukur 
kemampuan menganalisis, menilai dan mencipta. Oleh karena itu soal tersebut cenderung kompeks dan membutuhkan usaha untuk menyelesaikannya. Berdasarkan penjelasan tersebut, dapat disimpulkan bahwa soal PISA level 4-6 merupakan soal HOTS yang juga merupakan soal tidak rutin, cenderung kompleks, membutuhkan usaha dan kemampuan tinggi untuk menyelesaikannya.

Berdasarkan penelitian yang dilakukan oleh Fatimah, dkk. (2019), terdapat 2 dari 3 subjek yang masih belum bisa menyelesaikan soal PISA level 5 yang merupakan soal PISA kategori HOTS. Hal ini dikarenakan siswa tersebut tidak memenuhi fase-fase berpikir tingkat tinggi dengan baik. Oleh karena itu, penelitian ini akan mendeskripsikan proses berfikir matematis siswa yang ditinjau dari fase berpikir berdasarkan teori Mason, dkk. (2010).

Terdapat beberapa indikator pada setiap aspek yang ada dalam fase berpikir matematis siswa. Beberapa indikator dalam fase entry adalah memahami soal dengan cara mengurutkan informasi. Salah satu indikator dalam fase attack adalah membuat perencanaan penyelesaian dan menyelesaikan soal. Salah satu indikator dalam fase review adalah mengecek perhitungan dan ketepatan langkah dalam penyelesaian soal (Wardhani, dkk., 2016). Lebih lanjut Fatimah, dkk. (2019) menjabarkan indikator proses berpikir matematis siswa saat melibatkan kemampuan berpikir tingkat tinggi.

Untuk membangun proses berpikir siswa dalam memecahkan soal matematika dapat diberikan beberapa bantuan (Daya, Lambertus, \& Sudia, 2017). Bantuan ini disebut scaffolding. Hal ini sejalan dengan pendapat Vigotsky dalam Jo An \& Cao (2014) yang menyatakan bahwa "scaffolding refers to temporary support provided by the teacher, more capable peers, or computer tutors to help student solve problem or carry out a task that they cannot accomplish independently". Berdasarkan pernyataan tersebut maka scaffolding dapat digunakan guru untuk membantu siswa menyelesaikan masalah.

Sebelumnya, telah ada penelitian tentang proses berpikir matematis siswa, namun belum ada yang memfokuskan pada penyelesaian soal PISA kategori HOTS dan pemberian scaffoldingnya Terdapat penelitian yang dilakukan oleh Fatimah, dkk. (2019) yang membahas tentang proses berpikir tingkat tinggi menggunakan soal PISA dan scaffolding. Penelitian tersebut lebih memfokuskan proses berpikir tingkat tinggi siswa SMP. Soal PISA yang digunakan terbatas pada satu level saja yaitu level 5. Subjek yang diambil merupakan siswa unggulan. Pada penelitian ini akan berfokus pada proses berpikir matematis siswa SMP dalam menyelesaikan soal PISA kategori HOTS dan scaffoldingnya. Soal HOTS yang digunakan adalah soal PISA level 5 dan 6. Subjek yang dipilih berasal dari sekolah pinggiran kota, sehingga akan mempengaruhi pola berpikir matematis siswanya. Scaffolding yang dimaksud pada penelitian ini adalah pemberian bantuan kepada siswa untuk menyelesaikan soal PISA kategori HOTS sehingga siswa tersebut dapat memenuhi seluruh fase berpikir matematis dengan baik. Scaffolding akan diberikan oleh peneliti ketika siswa mengalami stuck dalam proses berpikir matematisnya.

Pemberian scaffolding ini didasarkan pada level scaffolding yang dikembangkan oleh Anghileri (2006) yaitu level 1 (enviromental provisions), level 2 (explaining, reviewing, and restructuring), dan level 3 (developing conceptual thinking). Pada level 1, scaffolding yang diberikan berupa pemberian bahan ajar mengkondisikan lingkungan belajar. Pemberian bahan ajar misalnya lembar kerja siswa yang diberikan oleh guru atau media yang mempermudah siswa untuk memahami masalah. Pada level 2 scaffolding yang diberikan berupa memberikan penjelasan oleh guru atau orang yang berkompeten untuk membantu siswa memfokuskan kembali perhatian siswa dan memberikan kesempatan kepada siswa untuk mengembangkan sendiri kemampuannya dan membangun ulang pemahaman siswa. Pada level 3 dilakukan dengan cara mengembangkan pemikiran konseptual siswa. Scaffolding level 1 adalah scaffolding yang diberikan kepada siswa secara berkelompok, sedangkan level 2 dan level 3 diberikan kepada siswa secara individu. Oleh karena itu, pada penelitian ini level scaffolding yang digunakan mengacu pada level 2 dan 3.

Menurut Hasan (2015) scaffolding merupakan pemberian bantuan secukupnya kepada siswa yang memiliki kemampuan yang lebih rendah didalam zona of proximal development (ZPD). Setiap siswa memiliki ZPD yang berbeda-beda, sehingga besar scaffolding yang diberikan kepada siswa juga berbeda-beda (Retnodari, dkk., 2020).

Hasil penelitian Isroil, dkk. (2017) menunjukkan bahwa kemampuan matematika dapat memengaruhi cara berpikir siswa. Siswa yang memiliki kemampuan matematika tinggi memiliki kemampuan menyelesaikan soal dengan baik. sebaliknya, siswa yang memiliki kemampuan matematika rendah memiliki kemampuan menyelesaikan soal yang kurang baik.

Berdasarkan permasalahan di atas, penelitian ini bertujuan untuk mendeskripsikan proses berpikir matematis siswa dalam menyelesaikan soal PISA kategori HOTS dan mendeskripsikan pemberian scaffoldingnya.

\section{METODE}

Jenis penelitian ini adalah penelitian deskriptif kualitatif. Subjek penelitian ini adalah 3 siswa kelas IX SMP di Sidoarjo yang terdiri dari satu siswa berkemampuan 
matematika tinggi, satu siswa berkemampuan matematika sedang dan satu siswa berkemampuan matematika rendah.

Pemilihan subjek dilakukan dengan cara memberikan tes kemampuan matematika (TKM) kepada 31 siswa kelas IX SMP yang berasal dari lingkungan peneliti yaitu Kecamatan Krembung, Kabupaten Sidoarjo. Kemudian mengelompokkan hasil tes kemampuan matematika ke dalam 3 kategori yaitu siswa berkemampuan matematika tinggi, siswa berkemampuan matematika sedang dan siswa berkemampuan matematika rendah. Dari hasil pengelompokkan tersebut diperoleh data sebagai berikut

Tabel 1. Hasil Tes Kemampuan Matematika

\begin{tabular}{|c|c|}
\hline Kategori & Jumlah \\
\hline Tinggi & 3 \\
\hline Sedang & 8 \\
\hline Rendah & 20 \\
\hline
\end{tabular}

Berdasarkan hasil data di atas, ditetapkan 3 subjek yang memiliki nilai tinggi dari masing-masing kategori dan bersedia serta sukarela untuk menjadi subjek penelitian. Berikut ini adalah subjek yang terpilih.

Tabel 2. Nilai Subjek Terpilih

\begin{tabular}{|c|c|c|}
\hline Subjek & Kategori & Nilai \\
\hline TRM & Tinggi & 88 \\
\hline FSF & Sedang & 70 \\
\hline NMR & Rendah & 37 \\
\hline
\end{tabular}

Instrumen yang digunakan yaitu tes soal PISA level 5-6 dan wawancara. Soal PISA yang digunakan telah divalidasi oleh dosen matematika. Hal yang dicermati pada proses validasi soal meliputi aspek kesesuaian soal dengan tujuan peneliti, aspek bahasa dan kejelasan soal termasuk penggunaan kalimat serta gambar yang digunakan. Dengan demikian soal tes layak digunakan dalam penelitian. Tes soal PISA terdiri dari tiga soal, dua soal merupakan soal PISA kategori HOTS yaitu level 5 dan satu soal level 6. Tes tersebut harus diselesaikan dalam waktu 45 menit. Berikut ini adalah soal tes yang digunakan.

1. Sebuah tempat penjualan pizza menjual dua buah pizza yang berbeda ukuran, namun memiliki rasa dan ketebalan yang sama. Pizza yang kecil memiliki diameter $30 \mathrm{~cm}$ dan dijual dengan harga Rp60.000,dan yang besar memiliki diameter $40 \mathrm{~cm}$ dan dijual dengan harga Rp80.000,. Dengan mempertimbangkan ukuran dan harga, manakah pizza yang lebih murah? Jelaskan alasanmu.

2. Seorang arsitek sedang berencana membangun ruang berjemur di lantai atas rumah. Keempat dinding ruang berjemur tersebut adalah panel kaca bening persegi. Atapnya dibuat menggunakan empat panel kaca bening berbentuk trapesium yang kongruen dan satu panel kaca berwarna berbentuk setengah segi delapan beraturan. Rancangan ruang berjemur tersebut dapat dilihat pada gambar di bawah ini.
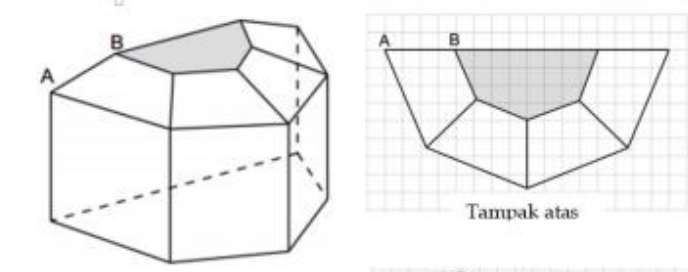

$$
\begin{aligned}
& \text { Skala yang digunakan } \\
& \text { untuk menggambar } \\
& \text { ruang berjemur adalah } \\
& 1 \mathrm{~cm}: 1 \mathrm{~m}
\end{aligned}
$$

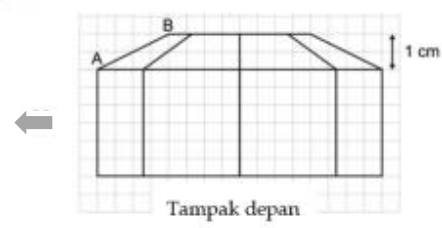

Tepi AB adalah salah satu panel atap. Berapakah panjang AB sebenarnya?

3. Mika sedang bersepeda dengan sepeda barunya. Terdapat speedometer di sepedanya. Speedometer tersebut menunjukan jarak yang ditempuh Mika dan kecepatan bersepedanya. Mika membutuhkan waktu 10 menit untuk berangkat dari rumah ke sekolah yang berjarak $2 \mathrm{~km}$. Saat pulang Mika melewati rute yang lebih pendek yaitu $1,8 \mathrm{~km}$ dan membutuhkan waktu 8 menit. Berapakah kecepatan rata-rata Mika dalam $\mathrm{km} / \mathrm{jam}$ untuk perjalanannya ke sekolah dan pulang dari sekolah?

Selanjutnya dilakukan wawancara dengan subjek terpilih. Wawancara dilakukan dengan tatap muka dan direkam untuk memudahkan peneliti dalam menganalisis data. Wawancara dilakukan setelah subjek menyelesaikan soal tes PISA dan peneliti menganalisis jawaban subjek.

\begin{tabular}{|c|c|c|}
\hline Tahap & Aspek & Indikator \\
\hline Entry & Know & $\begin{array}{l}\text { 1. Membaca soal dengan } \\
\text { seksama } \\
\text { 2. Menuliskan apa yang } \\
\text { ditanyakan } \\
\text { 3. Memeriksa keterkaitan antar } \\
\text { item yang diketahui, apakah } \\
\text { soal layak dikerjakan atau } \\
\text { tidak } \\
\text { 4. Menyadari adanya } \\
\text { ide/pengalaman/fakta lain } \\
\text { yang relevan }\end{array}$ \\
\hline
\end{tabular}
Data hasil tes soal PISA dan wawancara dianalisis dengan indikator proses berpikir matematis sebagai berikut.

Tabel 3. Indikator Proses Berpikir Matematis 


\begin{tabular}{|c|c|c|}
\hline & & $\begin{array}{l}\text { 5. Mengetahui soal lain yang } \\
\text { mirip dengan soal yang } \\
\text { dihadapi }\end{array}$ \\
\hline & Want & $\begin{array}{l}\text { 1. Mengelompokkan informasi } \\
\text { dan mengurutkan soal } \\
\text { 2. Ingin menyelesaikan soal } \\
\text { 3. Ingin membuktikan suatu hal } \\
\text { yang diklaim benar }\end{array}$ \\
\hline & $\begin{array}{l}\text { Introdu } \\
\text { ce }\end{array}$ & $\begin{array}{l}\text { 1. Memahami soal dengan } \\
\text { membuat gambar, diagram, } \\
\text { dll } \\
\text { 2. Memilih elemen yang perlu } \\
\text { dimisalkan dalam bentuk } \\
\text { simbol atau memilih simbol } \\
\text { yang tepat untuk } \\
\text { memisalhkan suatu elemen } \\
\text { 3. Menuliskan hal-hal yang } \\
\text { diketahui dari soal }\end{array}$ \\
\hline \multirow{3}{*}{ Attack } & Try & $\begin{array}{l}\text { 1. Mengajukan dugaan atau } \\
\text { renacana penyelesaian soal } \\
\text { 2. Memodifikasi dugaan yang } \\
\text { salah agar menjadi benar }\end{array}$ \\
\hline & Maybe & $\begin{array}{l}\text { 1. Mencoba dugaan atau rencana } \\
\text { yang telah dibuat untuk } \\
\text { menyelesaikan soal }\end{array}$ \\
\hline & Why & $\begin{array}{l}\text { 1. Mempunyai alasan logis } \\
\text { dalam menerima atau } \\
\text { menolak suatu dugaan } \\
\text { 2. Mempunyai alasan logis pada } \\
\text { setiap langkah-langkah } \\
\text { penyelesaiannya }\end{array}$ \\
\hline \multirow{3}{*}{ Review } & Check & $\begin{array}{l}\text { 1. Memeriksa perhitungan } \\
\text { 2. Memeriksa ketepatan alasan } \\
\text { alasan pada langkah } \\
\text { penyelesaian } \\
\text { 3. Memeriksa kesesuaian } \\
\text { langkah penyelesaian dengan } \\
\text { yang ditanyakan }\end{array}$ \\
\hline & Reflect & $\begin{array}{l}\text { 1. Merefleksi ide-ide ketika } \\
\text { menyelesaikan masalah } \\
\text { termasuk mengetahui bagian- } \\
\text { bagian yang sulit dan hal hal } \\
\text { yang dapat dipelajari dari } \\
\text { penyelesaian yang dilakukan } \\
\text { 2. Merefleksi alasan pada setiap } \\
\text { langkah } \\
\text { 3. Merefleksi dugaan-dugaan } \\
\text { sementara }\end{array}$ \\
\hline & Extand & $\begin{array}{l}\text { 1. Mencoba menyelesaikan } \\
\text { permasalahan serupa dengan } \\
\text { perubahan hal-hal yang }\end{array}$ \\
\hline
\end{tabular}

\begin{tabular}{|l|l|l|}
\hline & $\begin{array}{l}\text { diketahui dan hal-hal yang } \\
\text { ditanyakan }\end{array}$ \\
& $\begin{array}{l}\text { 2. Mencari cara penyelesaian } \\
\text { yang lain }\end{array}$ \\
\hline
\end{tabular}

Adaptasi dari (Fatimah, dkk., 2019)

Jika terdapat subjek yang belum bisa menyelesaikan soal PISA HOTS dengan benar dan belum melampaui fasefase berpikir matematis maka peneliti memberikan scaffolding sebagai upaya untuk membantu siswa dalam menyelesaikan soal PISA kategori HOTS.

\section{HASIL DAN PEMBAHASAN}

\section{Proses Berpikir Matematis Siswa dalam Menyelesaikan Soal PISA Kategori HOTS.}

Dalam menyelesaiakan soal PISA nomor 1 subjek berkemampuan matematika tinggi (S1) dapat menemukan solusi yang tepat. Hal ini dapat dilihat dalam lembar jawaban S1 pada gambar 1 sebagai berikut.

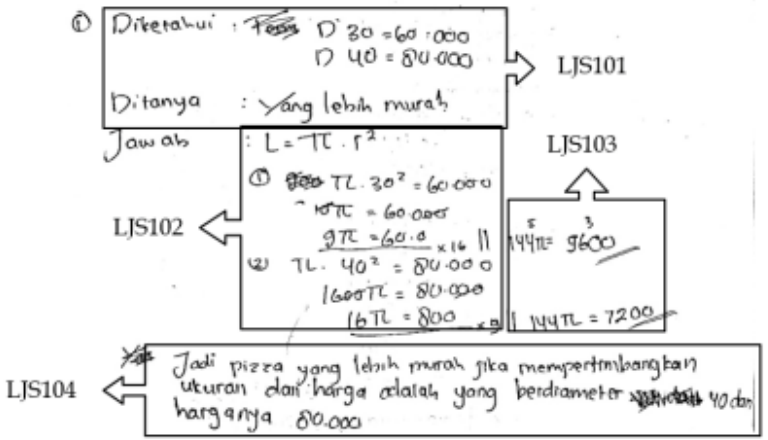

Gambar 1. Lembar Jawaban Tes S1

Saat wawancara, S1 mampu menjelaskan dengan baik tahapan-tahapan yang dilakukan selama memahami masalah. Berikut ini kutipan wawancara dengan S1.

P : Apa yang kamu lakukan pertama kali setelah saya beri soal?

S101: Baca soal kak. Terus saya pahami soalnya.

$\mathrm{P} \quad$ : Seperti apa caranya

S102: Saya cari yang diketahui dan ditanyakan. Saya cari yang penting-penting gitu kak

Berdasarkan kutipan wawancara S1, dapat diketahui bahwa proses berpikir S1 dimulai dengan fase entry. Pada [S101] hal yang pertama kali dilakukan setelah menerima soal adalah membaca soal kemudian menentukan hal-hal yang diketahui dan hal-hal yang ditanyakan. Hal ini mengidentifikasikan bahwa subjek berusaha untuk memahami soal dengan baik. Dengan demikian subjek dapat dikatakan memenuhi indikator aspek know. Kemudian S1 menentukan informasi yang penting dan mengelompokkannya. Pada [LJS101] S1 menuliskan apa yang diketahui pada soal. Dengan demikian S1 memenuhi aspek introduce. Sehingga proses berpikir matematis $\mathrm{S} 1$ dimulai pada fase entry dan melampaui aspek know, want, dan introduce. 
$\mathrm{P} \quad$ : Bagaimana caramu untuk menyelesaikan soal ini?

S103: Membandingkan antara harga dan luas pizza

$\mathrm{P} \quad$ : Bagaimana caramu untuk membandingkan?

S104: Di situ kan diketahui lingkaran, terus tanda sama dengan bukan nilai aslinya kak, bukan nilai asli dari perhitungan luas pizza. Tapi harganya saya bandingkan

P : Lalu jika bukan nilai aslinya kenapa menggunakan tanda sama dengan?

S105: Sebenarnya bukan tanda sama dengan kak, Cuma saya buat gitu soalnya saya tidak kepikiran dibuat tanda apa.

$\mathrm{P} \quad$ : Setelah itu bagaimana?

S106: Saya cari luas pizza masing-masing kak. Ternyata kalau luasnya beda harganya juga beda. Jadi belum bisa dibandingkan. Setelah itu saya samakan luasnya, ternyata harganya juga berbeda. Baru bisa dibandingkan kak. Saya cari yang harganya lebih murah.

Proses berpikir matematis S1 dilanjutkan dengan mencari cara agar bisa menyelesaikan soal yang diberikan. S1 mengaitkan hal hal yang diketahui dengan yang ditanyakan. S1 memutuskan untuk menggunakan rumus luas lingkaran untuk menghitung ukuran masing-masing pizza. Berdasarkan [LJS102] S1 membuat persamaan matematika yang didapat dari menyamakan luas lingkaran dengan harga, namun pada [S104] S1 menjelaskan bahwa tanda sama dengan bukan merupakan nilai sebenarnya melainkan untuk membandingkan luas dengan harga. Hal ini dikarenakan karena S1 tidak tahu tanda yang tepat untuk membandingkan luas dengan harganya. Berdasarkaan [S106], setelah mendapatkan luas masingmasing pizza S1 menyamakan luas pizza dengan cara mengalikan persamaan yg diperoleh dari harga dan luas pizza berdiamater $30 \mathrm{~cm}$ dengan 16 serta persamaan yang diperoleh dari luas dan harga pizza berdiameter $40 \mathrm{~cm}$ dengan 16. Didapatkan luas pizza yang sama dengan harga yang berbeda seperti yang tampak pada [LJS103]. Kemudian S1 membandingkan dua persamaan tersebut dan menyimpulkan bahwa pizza yang termurah adalah pizza yang berdiameter $40 \mathrm{~cm}$. Oleh karena itu, S1 memenuhi aspek try, why, dan maybe pada fase attack.

Setelah menyelesaikan soal nomor 1, S1 langsung melanjutkan menyelesaikan soal nomor 2, sehingga S1 tidak memenuhi semua indikator fase review.

Dalam menyelesaiakan soal PISA nomor 2, subjek berkemampuan matematika tinggi (S1) bisa menyelesaikan soal dengan benar. Berikut ini adalah lembar jawaban dan deskripsi proses berpikir matematis S1 dalam menyelesaikan soal PISA nomor 2.

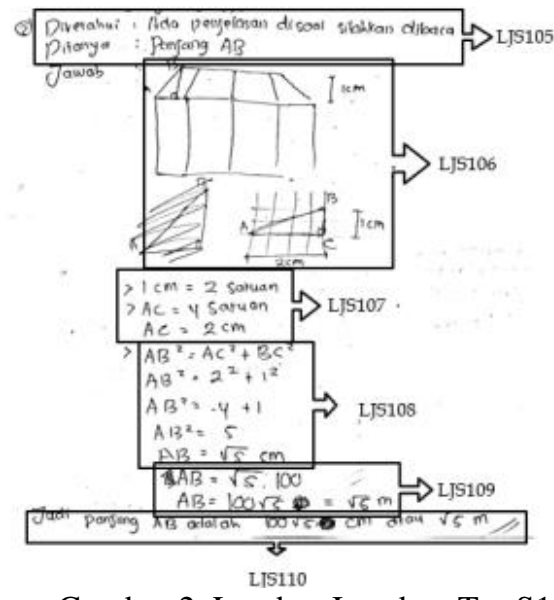

Gambar 2. Lembar Jawaban Tes S1

P : Apa yang kamu lakukan pertama kali saat melihat soal?

S107: Melihat gambarnya baru membaca soalnya, kak.

$\mathrm{P} \quad$ : Setelah itu bagaimana?

S108: Saya lihat skala dan kotak-kotak pada gambar dikertas berpetak-petaknya. Setelah itu saya tulis diketahui dan ditanya, tapi karena yang diketahui itu banyak dan ada yang berupa gambar jadi saya tulis seperti itu kak

S108: Saya lihat skala dan kotak-kotak pada gambar dikertas berpetak-petaknya. Setelah itu saya tulis diketahui dan ditanya, tapi karena yang diketahui itu banyak dan ada yang berupa gambar jadi saya tulis seperti itu kak

$\mathrm{P} \quad$ : Apa yang dikeahui di soal?

S109: Ini gambarnya kak, AB itu bagian ini dan tinggi panel $1 \mathrm{~cm}$ (menunjukan gambar pada soal). Terus skala vang digunakan digambar itu $1 \mathrm{~cm}: 1 \mathrm{~m}$

Proses berpikir matematis $\mathrm{S} 1$ dalam menyelesaikan soal PISA nomor 2 dimulai dengan fase entry ditandai dengan S1 mulai melihat gambar dan membaca soal. Pada [LJS105] S1 tidak menuliskan hal-hal yang diketahui dengan detail, namun pada [S108] S1 dapat menjelaskan hal-hal yang diketahui dengan baik. Selanjutnya pada [LJS106] S1 mengelompokkan informasi yang penting pada soal dan menggambar ulang berupa segitiga $A B C$ dengan memberikan simbol-simbol baru. Oleh itu proses berpikir matematis $\mathrm{S} 1$ dimulai dengan fase entry dengan memenuhi indikator know, want, dan introduce.

Proses berpikir matematis S1 dilanjutkan dengan membuat dugaan penyelesaian. Hal ini dilakukan S1 dengan cara melihat petak-petak pada gambar berpetak yang terdapat dari soal. Pada [LJS107] S1 mendapatkan informasi bahwa 2 petak mewakili $1 \mathrm{~cm}$ dan $\mathrm{AC}$ adalah 4 petak. oleh karena itu, S1 menyimpulkan panjang AC adalah $2 \mathrm{~cm}$. Selanjutnya pada [S112] S1 mengatakan bahwa S1 menggunakan konsep phytagoras karena diketahui panjang dua sisi segitiga dan mencari panjang segitiga yang lain serta segitiganya berbentuk segitiga siku-siku. Hal ini sesuai dengan [LJS108] dimana S1 menuliskan teorema phytagoras untuk mencari sisi miring yaitu AB. Pada [S113] S1 menjelaskan bahwa setelah menghitung panjang $\mathrm{AB}, \mathrm{S} 1$ menghitung panjang $\mathrm{AB}$ 
sebenarnya dengan mengalikan panjang AB pada gambar dengan 100 karena skala yang digunakan pada gambar adalah $1 \mathrm{~cm}: 1 \mathrm{~m}$ yang artinya 1: 100. Selanjutnya pada [LJS110] S1 menyimpulkan bahwa panjang AB sebenarnya dalam satuan $\mathrm{cm}$ maupun $\mathrm{m}$. Oleh karena itu proses berpikir matematis $\mathrm{S} 1$ dilanjutkan dengan fase attack dengan memenuhi indikator aspek try, maybe, dan why. Berikut ini adalah kutipan wawancara dengan S1.

$\mathrm{P} \quad$ : Setelah itu bagaimana?

S110: Saya melihat kotak-kotak digambarnya ini, kak. Saya lihat kalau 2 kotak itu $1 \mathrm{~cm}$. Terus saya gambar ulang. Nah, sisi yang bawah ini kan 4 kotak, jadinya $2 \mathrm{~cm}$

$\mathrm{P} \quad$ : Setelah itu rumus-rumus apa yang kamu gunakan di jawaban ini?

S111: Saya pakai rumus phytagoras kak.

$\mathrm{P} \quad$ : Mengapa menggunakan rumus itu?

S112: Setelah saya gambar ulang ini kan jadi segitiga siku-siku. Terus juga sudah menemukan panjang dua sisinya. Jadi bisa menggunakan rumus phytagoras untuk mencari $\mathrm{AB}$.

$\mathrm{P}$ : Setelah menemukan $\mathrm{AB}$, mengapa dikallikan 100 lagi?

S113: Karena yang saya cari tadi itu panjang AB kalau digambar ini kak. Terus saya cari panjang AB sebenarnya yang digedung. Yang diketahui skalanya $1 \mathrm{~cm}$ : $1 \mathrm{~m}$ jadinya 1:100. Berarti kalau dapat $\sqrt{5} \mathrm{~cm}$ berarti $\sqrt{5} \times 100 \mathrm{~cm}$

Berdasarkan [S114] setelah memberikan kesimpulan jawaban, S1 memeriksa kembali jawabannya. Hal ini dilakukan dengan cara memeriksa gambar/sketsa yang dibuat, mencocokan ulang dengan yang ada di soal. Kemudian S1 memeriksa perhitungan, khususnya pada perhitungan menggunakan rumus phytagoras karena hasil akhirnya bukan bilangan bulat. Pada [S116] S1 juga mengatakan bahwa S1 merefleksi setiap langkah penyelesaian. Selanjutnya memeriksa kesesuaian kesimpulan jawaban dengan yang ditanyakan. Oleh karena itu, proses berpikir matematis S1 dilanjutkan dengan fase review dengan memenuhi indikator check, reflect, dan extand. Berikut ini adalah kutipan wawancara dengan S1.

$\mathrm{P} \quad$ : Setelah menulis kesimpulan ini, apa yang kamu lakukan?

S114: kalau nomor 2 saya periksa lagi, karena saya yakin dengan cara yang saya gunakan, kak. Jadi saya periksa hitungannya.

$\mathrm{P} \quad$ : Bagian-bagian mana yang kamu periksa?

S115: Ini kak, saya cocokan gambar yang saya buat sama yang di soal dan bagian mencari panjang $\mathrm{AB}$ saat menggunkan rumus phytagoras, karena saat dihitung hasilnya tidak bulat, saya sedikit tidak yakin, kak. Jadi saya hitung ulang.

$\mathrm{P} \quad$ : Apakah ada yang kamu periksa lagi?

S116: bukan meriksa, kak. Tapi saya pikir lagi caranya sudah benar apa belum dan saya yakin benar. Terus saya mikir kesimpulannya sudah bisa menjawab yang ditanyakan atau tidak, kak.
Dalam menyelesaiakan soal PISA nomor 3, subjek berkemampuan matematika tinggi (S1) belum bisa menyelesaikan soal dengan benar. Berikut ini adalah lembar jawaban dan deskripsi proses berpikir matematis $\mathrm{S} 1$ dalam menyelesaikan soal PISA nomor 3.

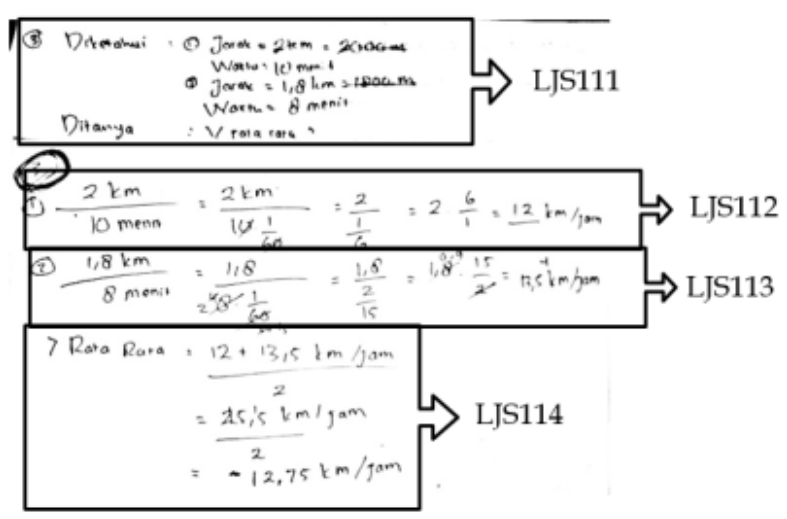

Gambar 3. Lembar Jawaban Tes S1

Proses berpikir matematis S1 dimulai dengan fase entry. Berikut ini adalah kutipan wawancara dengan S1.

P : Apa yang pertama kali kamu lakukan ketika melihat soal?

S117: Membaca soal, kak. Tapi sedikit kurang paham jadi saya baca ulang-ulang terus saya buat ilustrasi rutenya.

$\mathrm{P} \quad$ : Setelah itu bagaimana?

S118: sama seperti soal soal sebelumnya kak, saya cari yang diketahui dan yang ditanyakan.

Fase entry ditandai dengan S1 memulai proses berpikir dengan membaca soal dan membaut sketsa dari informasi yang diketahui di soal. Pada [S117] S1 mengatakan bahwa S1 mengidentifikasi hal-hal yang diketahui dan ditanyakan. Hal ini sesuai dengan [LJS111] dimana S1 menuliskan informasi yang diketahui dan ditanyakan. Oleh karena itu, pada fase entry S1 memenuhi aspek know, want, dan introduce.

Proses berpikir matematis S1 dilanjutkan dengan memberikan dugaan penyelesaian. Pada [S120] S1 menjelaskan dugaan penyelesaian yang pertama dengan menggunakan rumus kecepatan. Kemudian S1 mengubah satuan jarak saat berangkat yaitu satuan $\mathrm{km}$ menjadi $\mathrm{m}$. S1 memberikan alasan bahwa jika dibuat satuan m maka nilai jarak jika dibagi dengan waktu hasilnya akan menjadi bilangan bulat, dengan demikian akan mempermudah perhitungan. Selanjutnya S1 mengoperasikan bilangan sehingga mendapatkan kecepatan saat berangkat dan kecepatan saat pulang. Pada [S123] S1 menjelaskan bahwa S1 menghitung kecepatan rata-rata menggunakan rumus rata-rata yang didapat ketika belajar tentang data. Selanjutnya S1 menghitung dengan rumus yang dikatahuinya. Setelah mendapat kecepatan rata-rata, S1 mengubah satuan yang awalnya m/menit menjadi km/jam. setelah itu S1 memberikan kesimpulan. Hal ini 
menunjukkan bahwa S1 memenuhi aspek try dan maybe pada fase attack. Berikut ini adalah kutipan wawancara dengan $\mathrm{S} 1$.

P : Setelah itu, apa yang kamu lakukan?

S119: yang bagian soal ini saya mengerjakan dua kali, kak. Yang pertama itu yang saya coret-coret ini. Sebenarnya sudah selesai tapi ternyata pas saya periksa ada yang salah.

P : Coba ceritakan cara pengerjaanmu di jawaban yang dicoret ini sampai saat kamu menemukan titik kesalahanmu

S120: Setelah saya tulis yang diketahui dan ditanyakan saya langsung menghitung kecepatan, saya tandai dengan huruf V. Disini saya menguubah satuan $\mathrm{km}$ ke m kak

$\mathrm{P} \quad$ : Mengapa kamu mengubah satuan km ke m?

S121: Pikiran saya kalau tetap satuan km nanti kan dibagi 10, hasilnya itu 0 koma. Jadi saya ganti ke m agar hasilnya bukan bilangan koma. Jadi memudahkan hitungannya.

$\mathrm{P} \quad$ : Setelah itu bagaimana?

S122: Saya lanjut ya, kak. Setelah itu saya cari kecepatan saat berangkat dan kecepatan saat pulang. Itu hasil akhir satuannya masih dalam $\mathrm{m} /$ menit, kak. Setelah itu saya rata-ratakan kecepatannya.

$\mathrm{P} \quad$ : Bagaimana kamu merata-ratakan kecepatan itu?

S123: Kan kalau di data itu kecapatan sama dengan jumlah datanya dibagi banyaknya. Jadi saya buat seperti itu, kak. Setelah itu saya ubah satuannya jadi km/jam seperti yang ditanyakan. Nah disini saya salah kak.

$\mathrm{P} \quad$ : Bagaimana kamu tahu kalau bagian itu salah?

S124: Sebenarnya awalnya saya juga tidak sadar, kak. Waktu sudah selesai semua kan saya periksa. Saya ragu sama mengubah itu. Kan kalau menit ke jam seharusnya menjadi lebih sedikit karena 60 menit $=1$ jam. tapi punya saya malah menjadi lebih besar. Jadinya salah.

Pada [S124] S1 mengatakan bahwa setelah memberikan kesimpulan jawaban, S1 merasa ragu dengan langkah yang diberikan, sehingga S1 memeriksa langkahlangkah dan perhitungannya. S1 menemukan kesalahan dalam merubah satuan menit ke jam. Hal ini menunjukan bahwa S1 merefleksi langkah-langkah pengerjaan. Oleh karena itu, proses berpikir matematis S1 dilanjutkan dengan fase review dengan memenuhi indikator check, reflect, dan extand.

Proses berpikir matematis S1 selanjutnya adalah membuat dugaan penyelesaian baru. Pada saat wawancara S1 menjelaskan bahwa penyelesaian yang baru menggunakan cara seperti dugaan awal, namun pada langkah-langkah tertentu S1 mengubahnya. Pada [LJS112-LJS113] terlihat bahwa S1 mencari kecepatan saat berangkat dan kecepatan saat pulang. Berbeda dengan jawaban sebelumnya, jawaban yang baru ini S1 mengubah satuan waktu menjadi menit sesaui yang ditanyakan di soal. Dengan langkah yang sama dengan dugaan awal, S1 mencari rata-rata keceepatan dan mendapatkan hasil bahwa kecepatan rata-ratanya adalah $12,75 \mathrm{~km} / \mathrm{jam}$. Oleh karena itu, proses berpikir matematis S1 kembali ke fase attack dengan memenuhi aspek try dan maybe.

Dalam menyelesaikan soal PISA, subjek berkemampuan matematika sedang (S2) hanya bisa menyelesaikan satu soal dengan benar yaitu soal PISA nomor 1. Berikut ini adalah lembar jawaban dan proses berpikir matematis $\mathrm{S} 2$ saat menyelesaikan soal nomor 1 .

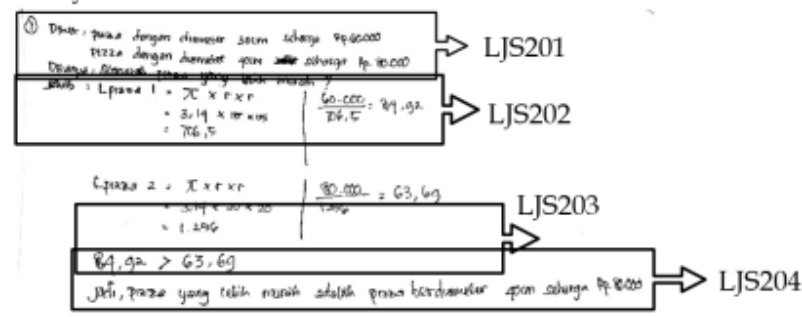

Gambar 4. Hasil Jawaban Tes S2

Berdasarkan gambar 9 di atas, S2 menuliskan hal yang diketahui dan hal yang ditanyakan, didukung saat wawancara [S202] S2 dapat menjelaskan langkah-langkah yang dilakukan untuk memahami masalah. S2 juga mampu menjelaskan hal yang diketahui dalam soal. Setelah membaca soal S2 mengaku berkeinginan untuk menyelesaiakan soal yang diberikan. Oleh karena itu, proses berpikir matematis subjek S2 dimulai pada fase entry dan memenuhi indikator aspek know, want, dan intoduce pada fase entry. Berikut ini adalah hasil kutipan wawancara dengan S2.

P : Apa yang kamu lakukan pertama kali setelah melihat soal

S201: Pertamanya membaca soal berulang-ulang, kemudian mencari yang diketahui dan ditanyakan.

P : Apa yang diketahui dan apa yang ditanya?

S202: 2 pizza, yang satu diameternya 30 harganya 60.000 dan pizza diameternya 40 harganya 80.000 . Terus yang ditanya itu pizza yang lebih murah

Selanjutkan S2 memasuki fase attack. Pada [S203] S2 memberikan dugaan dalam menyelesaikan masalah dan mencoba menyelesaikan soal. Berikut ini adalah kutipan wawancara dengan S2.

P : Setelah itu apa yang kamu lakukan saat mengerjakan soal?

S203: Karena di soal memperhatikan ukuran dan harga jadi saya cari ukuran pizzanya, kak. terus saya bagi dengan harganya.

$\mathrm{P} \quad$ : Mengapa kamu bagi?

S204: Saya bandingkan untuk mencari harga per $\mathrm{cm}^{2}$.

Setelah menuliskan hal yang diketahui dan ditanyakan S2 membuat dugaan penyelesaian. S2 menghubungkan hal yang diketahui dan ditanyakan. Dalam hal ini S2 mengaitkan antara bentuk pizza dengan ukuran pizza. S2 memberikan dugaan bahwa akan 
menggunakan konsep lingkaran karena bentuk pizza menyerupai lingkaran. Berdasarkan lembar jawaban [LJS202] S2 menentukan luas pizza yang berdiameter 30 $\mathrm{cm}$ kemudian membagi harga pizza yang memiliki diameter $30 \mathrm{~cm}$ dengan luas pizzanya. Dengan cara yang sama S2 juga menentukan luas pizza yang berdiameter 40 $\mathrm{cm}$ dan membagi harga pizza yang memiliki diameter 40 cm dengan luas pizzanya. Pada [S204] S2 mengatakan bahwa $\mathrm{S} 2$ menghitung harga per $\mathrm{cm}^{2}$ masing-masing pizza untuk menentukan pizza yang paling murah. Selanjunya S2 membandingkan harga per $\mathrm{cm}^{2}$ masing-masing pizza dan memberikan kesimpulan bahwa pizza berdiameter 40 cm lebih murah. Hal ini dapat dilihat pada [LJS204]. Pada fase attack, S2 mampu memenuhi aspek try karena telah memberikan dugaan dalam menyelesaikan masalah, aspek maybe karena dapat menyelesaikan soal dengan dugaan awal dan aspek why karena S2 mampu memberikan alasan-alasan yang logis dari setiap langkah penyelesaian.

S2 belum dapat menyelesaikan soal PISA nomor 2. Hal ini dapat dilihat pada lembar jawaban S2 sebagai berikut.

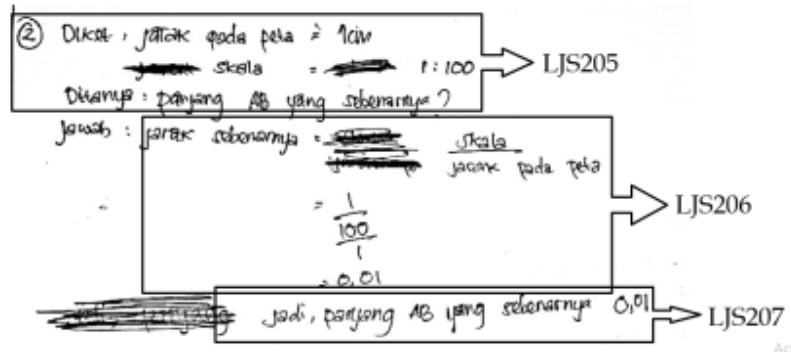

Gambar 5. Hasil Jawaban Tes S2

Proses berpikir matematis S2 dalam menyelesaikan soal PISA nomor 2 dimulai pada fase entry. Hal ini ditandai ketika subjek mulai membaca soal, mengidentifikasi hal-hal yang diketahui dan ditanyakan pada soal seperti yang terlihat pada [LJS205]. Setelah membaca soal dan menuliskan hal yang diketahui dan ditanyakan, S2 mengaku merasa penasaran dan berkeinginan untuk menyelesaiakan soal. Oleh karena itu, pada fase entry S2 memenuhi indikator know, want, dan intoduce.

Proses berpikir matematis subjek berlanjut pada fase attack. Pada fase ini, S2 mulai memikirkan dugaan-dugan dan rencana penyelesaian yang akan digunakan untuk menyelesaikan soal. Setelah menuliskan soal S2 mulai mencermati gambar dan skala yang digunakan. Berdasarkan [S206] S2 mengatakan bahwa S2 mencoba menggunakan rumus hubungan antara skala, jarak sebenarnya, dan jarak pada peta, namun S2 mengaku lupa dengan rumus yang sudah dihafal sebelumnya. Kemudian S2 mensubstitusikan hal yang diketahui ke rumus yang digunakan untuk menentukan hal yang ditanya yaitu panjang AB sebenarnya. Berdasarkan [S207] S2 mengatakan bahwa $\mathrm{S} 2$ menganggap panjang AB pada peta adalah $1 \mathrm{~cm}$ seperti yang diketahui pada soal. Hal ini sesuai dengan jawaban S2 [LJS206]. Selanjutnya S2 menyimpulkan bahwa panjang $\mathrm{AB}$ sebenarnya adalah 0,01. Berikut ini adalah kutipan wawancara dengan S2.

$\mathrm{P} \quad$ : Setelah itu apa yang kamu lakukan?

S205: Melihat gambarnya lagi, terus lihat skalanya.

$\mathrm{P} \quad$ : Setelah itu bagaimana?

S206: Karena yang ditanyakan jarak AB sebenarnya jadi pakai rumus jarak AB sebenarnya sama dengan skala dibagi jarak pada peta. Tapi saya tidak yakin rumusnya benar, karena saya sudah lupa, kak. Terus saya masukkan yang diketahui itu.

P : Berdasarkan hasil jawabanmu, apakah kamu menganggap $\mathrm{AB}$ pada peta itu panjangnya $1 \mathrm{~cm}$ ?

S207: Bagian itu juga saya ngawur kak, karena sebenarnya tidak diketahui panjang AB pada peta itu berapa, tapi ada yang diketahui $1 \mathrm{~cm}$. Saya juga tidak paham $1 \mathrm{~cm}$ itu panjang apa, kak. Jadi saya anggap $\mathrm{AB}$ pada peta panjangnya $1 \mathrm{~cm}$.

Dengan demikian, S2 memenuhi indikator aspek try karena dapat membuat dugaan dan rencana penyelesaian dan aspek maybe karena dapat mencoba menyelesaikan soal dengan rencana penyelesaian yang dibuatnya.

Subjek berkemampuan matematika sedang belum dapat menyelesaikan soal PISA nomor 3. Hal ini dapat dilihat pada lembar jawaban S2 sebagai berikut.

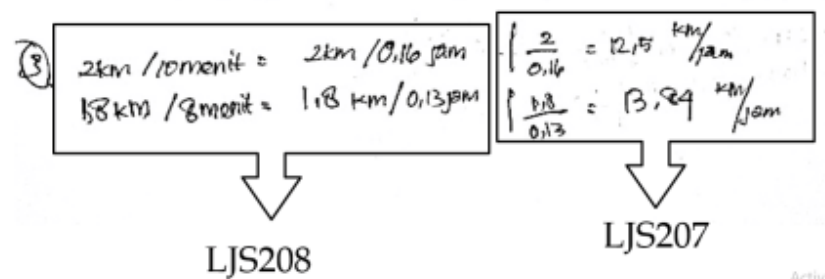

Gambar 6. Hasil Jawaban Tes S2

Proses berpikir matematis subjek berkemampuan matematika sedang dimulai dengan fase entry. Hal ini ditandai dengan subjek memulai membaca soal [S208]. Berdasarkan lembar jawaban, S2 tidak menuliskan hal yang diketahui dan ditanyakan di soal, namun saat wawancara [S209] S2 mengatakan bahwa S2 mengidentifikasi hal yang ditanyakan dan diketahui. S2 juga mampu menyebutkan hal-hal yang diketahui maupun yang ditanyakan dengan benar. Berikut ini adalah kutipan wawancara dengan $\mathrm{S} 2$.

$\mathrm{P} \quad$ : Apa yang kamu lakukan setelah melihat soal?

S208: Membaca soal terus mencari yang diketahui dan ditanyakan.

$\mathrm{P} \quad$ : Apa yang diketahui dan ditanyakan?

S209: Yang diketahui itu waktu yang dibutuhkan saat berangkat, jarak saat berangkat, waktu yang dibutuhkan saat pulang, dan jarak saat pulang.

Oleh karena itu, pada fase entry. Proses berpikir matematis S2 memenuhi indikator know, want, dan intoduce 
Proses berpikir matematis S2 berlanjut pada fase attack. Pada fase ini S2 membuat perencanaan jawaban. Hal ini dilakukan dengan cara meengaitkan hal yang diketahui dan yang ditanyakan. Berdasarkan [LJS208] S2 membagi jarak dengan waktu. Hal ini dikarenakan S2 ingin menghitung kecepatan saat perjalanan berangkat dan pulang. Kemudian S2 mengubah satuan menit ke jam karena yang ditanyakan dalam satuan jam [LJS208]. Selanjutnya S2 menghitung kecepatan masing-masing perjalanan [LJS209]. Kemudian S2 mengatakan bahwa S2 tidak bisa melanjutkan pengerjaan, karena S2 tidak memahami arti dari kecepatan rata-rata sehingga S2 tidak bisa memikirkan langkah selanjutnya yang digunakan. Oleh karena itu, S2 memenuhi indikator aspek try dan maybe pada fase attack.

S2 tidak melakukan pemeriksaan ulang terhadap semua jawaban, baik perhitungan maupun langkahlangkah penyelesaian. Oleh karena itu, S2 tidak memnuhi indikator pada fase review.

Subjek berkemampuan matematika rendah (S3) belum dapat menemukan solusi yang tepat untuk ketiga nomor. Hal ini dapat dilihat dalam lembar jawaban S3 pada gambar 7 sebagai berikut.

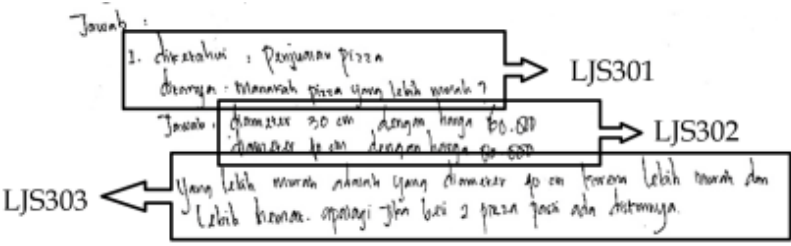

Gambar 7. Hasil Jawaban Tes S3

Proses berpikir matematis S3 dalam menyelesaikan soal PISA nomor 1 dimulai ketika S3 membaca soal [S301]. Berdasakan [LJS301] S3 menuliskan hal-hal yang diketahui dan yang ditanyakan, namun kurang tepat. Pada saat wawancara [S303] S3 juga tidak dapat menyebutkan hal-hal yang diketahui dengan benar. Hal ini mengentifikasikan hawa $\mathrm{S} 2$ belum mengetahui maksud dari soal. Oleh karena itu, proses berpikir matematis S2 dimulai dengan fase entry dengan memenuhi indikator know dan want. Berikut ini adalah kutipan wawancara dengan S3.

$\mathrm{P} \quad$ : Apa yang kamu lakukan setelah melihat soal?

S301: Membaca soal

$\mathrm{P} \quad$ : Setelah itu bagiamana?

S302: Ini kan soal bentuk cerita, jadi biasanya ada diketahui dan ditanya. Jadi saya nulis diketahui dan ditanya.

P : Apa yang diketahui dan apa yang ditanya dalam soal?

S303: Yang diketahui penjualan pizza yang ditanya mana pizza yang lebih murah.

P : Apa yang kamu lakukan setelah menulis diktahui dan ditanya?

S304: Mencoba menyelesaikan, terus menulis yang di

Selanjutnya S3 memasuki fase attack. Pada [S302]

S3 mengatakan bahwa S3 mencoba menyelesaikan soal dengan menuliskan hal-hal yang diketahui [LJS302]. Pada [LJS303] S3 menyimpulkan bahwa pizza yang berdiameter $40 \mathrm{~cm}$ adalah pizza yang paling murah tanpa melakukan perhitungan dan tidak disertai alasan yang logis. Hal ini juga didukung dengan hasil wawancara [S306] yang menunjukkan bahwa S3 tidak menggunakan cara namun hanya menebak jawaban saja. Berikut kutipan wawancara dengan S3.

$\mathrm{P} \quad$ : Bagaimana cara kamu menyelesaikannya?

S305: Saya tulis pizza dan harganya itu. Terus saya ngasal jawabnya.

$\mathrm{P} \quad$ : Mengapa kamu menyimpulkan bahwa pizza yang berdiamater $40 \mathrm{~cm}$ lebih murah?

S306: Tidak tahu, kak. Saya kepikiran seperti itu saja.

Hal ini mengidikasikan bahwa S3 belum bisa membuat dugaan penyelesaian. Proses berpikir matematis subjek tidak melalui fase attack karena tidak memenuhi indikator proses berpikir matematis pada fase attack

Proses berpikir matematis S3 juga tidak sampai pada fase review karena tidak memenuhi semua indikator pada fase review. Proses berpikir matematis S3 dalam menyelesaikan soal PISA nomor 1 dapat dilihat pada gambar di bawah ini.

Subjek berkemampuan matematika rendah (S3) juga belum bisa menyelesaikan soal PISA nomor 2 dengan benar. Berikut ini adalah lembar jawaban S3 untuk soal nomor 2 dan kutipan wawancara dengan S3

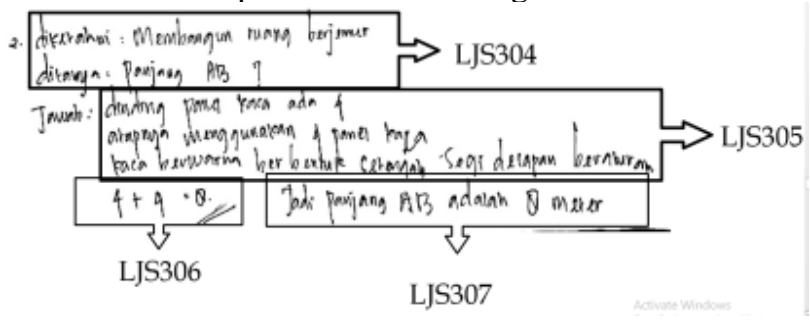

Gambar 8. Hasil Jawaban Tes S3

$\mathrm{P} \quad$ : Apa yang kamu lakukan setelah melihat soal

S307 : membaca soal, melihat gambarnya. Terus menuliskan diketahui dan ditanya

P : Mengapa kamu menulis membangun ruang berjemur sebagai yang diketahui

S308 : Tidak paham, kak. Mungkin karena soalnya

Proses berpikir matematis S3 dalam menyelesaikan soal PISA nomor 2 dimulai dengan fase entry. Hal ini ditandai ketika S3 mulai membaca soal dan mengidentifikasi gamba [S307]. Kemudian S3 menuliskan hal yang diketahui dan ditanyakan, namun dalam lembar jawaban [LJS304] hal hal yang diketahui tidak ditulis dengan benar. Saat wawancara [S308] S3 mengatakan bahwa S3 tidak mengerti tentang soal yang diberikan. Jadi, S3 tidak bisa membedakan informasi mana yang penting dan yang tidak diperlukan. Oleh karena itu, pada fase entry hanya memenuhi indikator aspek know dan want.

Proses berpikir matematis selanjutnya adalah saat S3 mulai merencanakan penyelesaian dan mencoba menyelesaikan soal. Setelah menuliskan hal yang diketahui dan ditanya S2 menuliskan informasi-informasi yang mengandung angka pada soal seperti yang terlihat pada [LJS0305]. Pada [S310] S3 menjelaskan bahwa hal 
ini dilakukan karena S3 ingin mencari panjang $\mathrm{AB}$ yang merupakan angka, sehingga S3 mencari informasi yang berupa angka. Selanjutnya S3 menambahkan semua angka yang diperolehnya yaitu $4+4=8$ seperti yang terlihat pada [LJS306]. Pada [S313] menjelaskan bahwa S3 tidak mempunyai alasan yang logis pada setiap jawabannya. Oleh karena itu pada fase attack S3 hanya memenuhi indikator aspek try dengan mencoba membuat rencana penyelesaian dengan cara mengidentifikasi informasi yang mengandung angka dan menjumlahkannya. Kemudian S3 menyimpulkan bahwa panjang $\mathrm{AB}$ adalah 8 seperti yang terlihat pada [LJS307] . Berikut ini adalah kutipan wawancara dengan S3.

$\mathrm{P} \quad$ : Apa yang kamu lakukan selanjutnya?

S309: Menulis ini, kak. Yang ada di soal

$\mathrm{P}$ : Mengapa kamu menulis informasi-informasi tersebut

S310: Saya cari yang ada angkanya, karena mencari panjang AB kan harus angka. Jadi saya cari angkaangka di soal.

$\mathrm{P} \quad$ : Terus angka 4+4 ini dari mana?

S311: Dari ini 4 dinding dan 4 kaca.

$\mathrm{P}$ : Mengapa angka yang kamu dapatkan kamu jumlahkan seperti itu?

S312: Untuk mencari panjang AB, kak.

$\mathrm{P}$ : Coba jelaskan, apa hubungannya panjang $\mathrm{AB}$ dengan banyak dinding dan kaca sehingga kamu menjumlahkannya?

S313: Saya asal jawab, kak. Sebenarnya saya tidak paham soalnya ini gimana.

Proses berpikir matematis S3 hanya sampai pada fase review. Hal ini dikarenakan S3 tidak memenuhi semua indikator proses berpikir pada fase review.

Sama seperti pada soal nomor 1 dan nomor 2, S3 juga tidak dapat menyelesaikan soal PISA nomor 3 dengan benar. Berikut ini adalah lembar jawaban S3 dalam menyelesaikan soal PISA nomor 3.

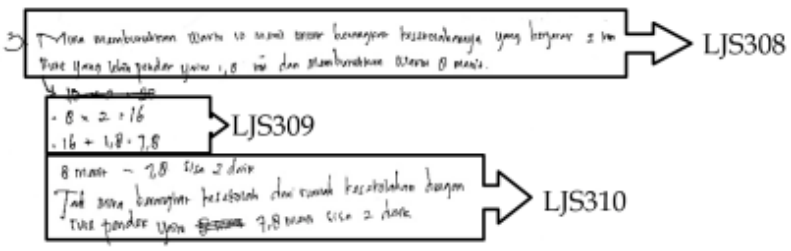

Gambar 9. Hasil Jawaban Tes S3

Proses berpikir matematis S3 saat mengerjakan soal dimulai pada fase entry ditandai dengan S3 memulai dengan membaca soal. Selanjutnya S3 mengidentifikasi dan menuliskan hal yang diketahui dalam soal [LJS308], namun S3 tidak menuliskan hal yang ditanyakan. Berdasarkan [S315] S3 tidak bisa menyebutkan hal-hal yang ditanyakan dengan benar. Hal ini mengidentifikasikan bahwa S3 belum memahami soal dengan baik. Sehingga pada fase entry S3 memenuhi indikator know dan want. Berikut ini adalah kutipan wawacara dengan S3
$\mathrm{P} \quad$ : Apa yang kamu lakukan setelah melihat soal?

S314: Membaca soal terus menjawab

$\mathrm{P}$ : Coba jelaskan apa yang ditanyakan pada soal

S315: Rata-ratanya Mika

$\mathrm{P} \quad$ : Apa yang kamu lakukan setelah itu?

S316: Menulis ini, kak. Yang ada di soal (menunjuk lembar jawaban)

$\mathrm{P} \quad$ : Setelah itu bagaimana?

S317: Saya kerjakan.

P : Bagaimana cara kamu menyelesaikan soal itu?

S318: Saya kalikan angka waktu berangkat

$\mathrm{P} \quad$ : Konsep apa yang kamu gunakan sehingga membuat jawaban seperti ini?

S319: Tidak tahu, kak. Cuma saya gabung-gabung aja kak

P : Coba kamu jelaskan lebih detail, bagaimana caramu menggabung-gabung hingga mendapat jawaban?

S320: 8 x 2 itu dari soal kak. Saya cari angka yang gampang saja pekaliannya. Setelah itu dapat 16 saya tambahkan dengan 1,8 yang jaraknya itu kak. Terus dapat 7,8. artinya artinya 8 menit itu 7,8 sisa 2 detik

$\mathrm{P} \quad$ : Mengapa kamu menulis informasi-informasi tersebut

S321: saya cari yang ada angkanya, karena mencari panjang AB kan harus angka. Jadi saya car angka-angka di soal.

Proses berpikir S3 selanjutnya memasuki fase attack ditandai dengan S3 mulai memikirkan rencana penyelesaian. Setelah menuliskan hal-hal yang diketahui di soal, S3 menggunakan konsep operasi hitung bilangan untuk menyelesaikan soal nomor 3. Pada [LJS309] S3 mengalikan 8 yang merupakan angka dari waktu yang dibutuhkan saat pulang dengan 2 yang merupakan angka dari jarak rute berangkat. Hal ini tidak sesuai dengan [S318] yang menjelaskan bahwa S3 mengalikan angkaangka yang diketahui saat berangkat. Hal ini menujukkan bahwa S3 tidak mempunyai alasan yang logis pada langkah ini. Selanjutnya S3 menjumlahkan 16 yang merupakan hasil perkalian sebelumnya dengan 1,8 yang merupakan jarak rute ketika pulang sehingga didapat hasil 7,8. Pada langkah ini S3 melakukan kesalahan perhitungan, namun pada sesi wawancara S3 menyadari kesalahan tersebut. Selanjutnya S3 mengaitkan antara waktu yang dibutuhkan saat pulang yaitu 8 menit dengan angka yang didapatkan dari hasil perhitungannya yaitu 7,8 . Dari kedua angka tersebut S3 menyimpulkan bahwa jawaban yang benar adalah 7,8 sisa 2 detik. S3 menjelaskan bahwa untuk menjadi 8 menit maka memerlukan 2 detik lagi. Kemudian S3 menyimpulkan bahwa rute pendek untuk kesekolah adalah 7,8 menit sisa 2 detik. Hal ini tidak sesuai dengan apa yang ditanyakan dan juga tidak sesuai dengan apa yang dikerjakan. Oleh karena itu, S3 hanya memenuhi indikator aspek try pada fase attack karena sudah memberikan dugaan penyelesaian dengan cara menggunakan konsep perkalian dan penjumlahan. 
Berikut ini adalah table proses berpikir matematis ketiga subjek

Tabel 4. Proses berpikir matematis ketiga subjek

\begin{tabular}{|c|c|c|}
\hline Subjek & $\begin{array}{l}\text { No } \\
\text { mor } \\
\text { soal }\end{array}$ & Proses berpikir matematis \\
\hline \multirow[t]{3}{*}{$\begin{array}{l}\text { Subjek } \\
\text { berkema } \\
\text { mpuan } \\
\text { matemati } \\
\text { ka tinggi } \\
\text { (S1) }\end{array}$} & 1 & $\begin{array}{l}\text { Proses berpikir matematis S1 } \\
\text { dimulai dengan fase entry dengan } \\
\text { memenuhi aspek know, want, dan } \\
\text { introduce. dilanjutkan dengan fase } \\
\text { attack dengan memenuhi aspek try, } \\
\text { maybe, dan why. }\end{array}$ \\
\hline & 2 & $\begin{array}{l}\text { dimulai dengan fase entry dengan } \\
\text { memenuhi aspek know, want, dan } \\
\text { introduce, selanjutnya memasuki } \\
\text { fase attack dengan memenuhi } \\
\text { indikator try, maybe dan why. } \\
\text { Kemudian berakhir pada fase review } \\
\text { dengan melampaui aspek check, } \\
\text { reflect, dan extand. }\end{array}$ \\
\hline & 3 & $\begin{array}{l}\text { Dimulai dengan fase entry dengan } \\
\text { memenuhi aspek know, want dan } \\
\text { introduce, selanjutnya memasuki } \\
\text { fase attack dengan memenuhi } \\
\text { indikator try dan maybe. Kemudian } \\
\text { berlanjut dengan pada fase review } \\
\text { dengan melampaui aspek check, } \\
\text { reflect, dan extand. Proses ini } \\
\text { mengulang kembali pada fase } \\
\text { attack. }\end{array}$ \\
\hline \multirow{3}{*}{$\begin{array}{l}\text { Subjek } \\
\text { berkema } \\
\text { mpuan } \\
\text { matemati } \\
\text { ka } \\
\text { sedang } \\
(\mathrm{S} 2)\end{array}$} & 1. & $\begin{array}{l}\text { dimulai dengan fase entry dengan } \\
\text { memenuhi aspek know, want, dan } \\
\text { introduce. Dilanjutkan dengan fase } \\
\text { attack dengan memenuhi aspek try, } \\
\text { maybe, dan why. }\end{array}$ \\
\hline & 2 & $\begin{array}{l}\text { Dimulai dengan fase entry dengan } \\
\text { memenuhi aspek know, want, dan } \\
\text { introduce. Selanjutnya memasuki } \\
\text { fase attack dengan memenuhi } \\
\text { indikator try dan maybe. }\end{array}$ \\
\hline & 3 & $\begin{array}{l}\text { Dimulai dengan fase entry dengan } \\
\text { memenuhi aspek know, want, dan } \\
\text { introduce. Kemudian proses ini } \\
\text { memasuki fase attack dengan } \\
\text { memenuhi indikator try dan maybe }\end{array}$ \\
\hline $\begin{array}{l}\text { Subjek } \\
\text { berkema } \\
\text { mpuan } \\
\text { matemati }\end{array}$ & 1 & $\begin{array}{l}\text { Dimulai dengan fase entry dengan } \\
\text { memenuhi aspek know dan want. } \\
\text { Proses ini juga berakhir pada fase } \\
\text { entry. }\end{array}$ \\
\hline
\end{tabular}

\begin{tabular}{|l|l|l|}
\hline \begin{tabular}{l} 
ka $\begin{array}{l}\text { Rendah } \\
\text { (S3) }\end{array}$ \\
\cline { 2 - 3 }
\end{tabular} & 2 & $\begin{array}{l}\text { Dimulai dengan fase entry dengan } \\
\text { memenuhi aspek know dan want. } \\
\text { Selanjutnya memasuki fase attack } \\
\text { dan hanya memenuhi indikator try. }\end{array}$ \\
\cline { 2 - 3 } 3 & $\begin{array}{l}\text { Dimulai dengan fase entry dengan } \\
\text { memenuhi aspek know dan want. } \\
\text { Kemudian proses ini memasuki fase } \\
\text { attack dengan memenuhi indikator } \\
\text { try. }\end{array}$ \\
\hline
\end{tabular}

\section{Pemberian Scaffolding}

Pemberian scaffolding kepada subjek bergantung dengan kemampuan subjek dalam memecahkan masalah. Scaffolding yang diberikan kepada masing-masing subjek berbeda. Scaffolding diberikan sampai subjek bisa melakukan proses berpikir matematis dengan baik, ditandai dengan memenuhi indikator berpikir matematis. Dengan demikan subjek bisa menyelesaikan soal PISA kategori HOTS dengan benar. Berikut ini adalah deskripsi scaffolding kepada masing-masing subjek.

S1 membutuhkan scaffolding dalam menyelesaikan soal PISA nomor 1 dan 3. Scaffolding pada fase attack diberikan ketika S1 menyelesaikan soal nomor 1 . Scaffolding yang diberikan adalah restructuring dengan memberikan pertanyaan-pertanyaan yang dapat membuat S1 menyadari konsep yang digunakan adalah perbandingan dua bersaran dengan satuan berbeda. S1 juga memerlukan sedikit bantuan pada fase review. Scaffolding ini membantu subjek untuk memeriksa dan merefleksi langkah-langkah perhitungan.

Scaffolding ketika S1 menyelesaikan soal nomor 3 adalah explaining, reviewing, dan rectructuring. Scaffolding ini diberikan ketika S1 memasuki fase attack. Scaffolding dilakukan dengan cara membantu mengingatkan subjek tentang konsep kecepatan rata-rata. Scaffolding berupa developing conteptual thingking juga diberikan pada fase review dengan cara memberikan S1 waktu untuk memikirkan cara lain dan meminta S1 menyelesaikan masalah yang sama ketika beberapa item yang diketahui diubah.

S2 membutuhkan scaffolding dalam menyelesaikan soal nomor 1, 2 dan 3. S2 membutuhkan bantuan pada fase review ketika menyelesaikan soal nomor 1 adalah. Scaffolding yang diberikan adalah reviewing dengan meminta subjek memeriksa setiap perhitungan dan merefleksi langkah-langkah penyelesaian. Scaffolding yang diberikan kepada S2 ketika menyelesaikan soal nomor 1 tidak banyak karena S2 sudah berhasil menemukan jawaban yang tepat.

S2 membutuhkan scaffolding pada fase attack S2 menyelesaikan soal nomor 2. Scaffolding yang diberikan adalah explaining, reviewing, and restructuring dengan memberikan beberapa pertanyaan tentang hubungan yang 
diketahui dengan yang. Selanjutnya memberikan pertanyaan-pertanyaan yang mengarahkan S2 untuk membuat sketsa segitiga siku-siku darigambar yang diketahui di soal. Kemudian membiarkan S2 memikirkan langkah-langkah selanjutnya yang akan digunakan hingga menyimpulkan jawaban. Sama seperti scaffolding saat menyelesaikan soal nomor 1, S2 juga memerlukan scaffolding berupa reviewing untuk memenuhi indikator fase review. Scaffolding berupa developing conteptual thingking juga diberikan dengan cara memberikan S2 waktu untuk memikirkan cara lain dan meminta S2 menyelesaikan masalah yang sama ketika beberapa item yang diketahui diubah.

Ketika menyelesaikan soal nomor 3, S2 memerlukan scaffolding pada fase attack dan review. Scaffolding ketika S2 menyelesaikan soal nomor 3 adalah explaining, reviewing, and restructuring dengan mengingatkan S2 dengan konsep kecepatan rata-rata. Kemudian membiarkan S2 untuk menyelesaikan soal sampai dengan menyimpulkan jawaban. Selanjutnya S2 juga memerlukan scaffolding berupa reviewing dengan cara meminta S2 untuk memeriksa perhitungan dan langkah-langkah penyelesaian. Scaffolding berupa developing conteptual thingking juga diberikan dengan cara memberikan S3 waktu untuk memikirkan cara lain dan meminta S3 menyelesaikan masalah yang sama ketika beberapa item yang diketahui diubah.

S3 memerlukan bantuan pada fase entry, attack maupun review. Scaffolding ketika S3 menyelesaikan soal nomor 1 adalah adalah explaining dengan meminta subjek untuk membaca ulang soal dengan teliti, membacakan ulang soal dengan memberikan penekanan pada informasiinformasi yang penting dan meminta S3 untuk menuliskan hal-hal yang diketahui dan yang ditanyakan. Scaffolding berupa Developing conceptual thinking juga diberikan kepada S3 dengan meminta S3 untuk membuat sketsa dari apa yang diketahui di soal agar memudahkan S3 untuk membuat dugaan penyelesaian.

Pada fase attack, scaffolding yang diberikan kepada $\mathrm{S} 3$ adalah explaining, reviewing, and restructuring dengan menanyakan hubungan yang diketahui yaitu diameter dan harga pizza dengan yang ditanyakan yaitu pizza yang lebih menguntungkan penjual. Kemudian membimbing S3 untuk mencari luas masing-masing pizza, menanyakan harga masing-masing pizza jika luasnya sama dan mengarahkan S3 menggunakan konsep perbandingan. Dengan demikian S3 mampu mencari harga per $\mathrm{cm}^{2}$ pada masing-masing pizza.

Pada fase review, scaffolding yang diberikan kepada S3 adalah reviewing dengan meminta S3 untuk memberikan kesimpulan jawaban, memeriksa perhitungan dan memeriksa langkah-langkah penyelesaian. Kemudian meminta subjek untuk merefleksi rumus yang digunakan dan kesesuaian antara kesimpulan dan yang ditanyakan. Scaffolding berupa developing conteptual thingking juga diberikan dengan cara memberikan S3 waktu untuk memikirkan cara lain dan meminta S3 menyelesaikan masalah yang sama ketika beberapa item yang diketahui diubah, namun S3 belum bisa menemukan cara lain dan menyelesaikan soal saat item yang diketahui di soal diubah. Hal ini dikarenakan S3 belum menguasai operasi bilangan pecahan. Oleh karena itu, subjek kesulitan ketika mencari harga per $\mathrm{cm}^{2}$ pizza.

Pada saat menyelesaikan soal nomor 2, S3 memerlukan scaffolding pada ketiga fase berpikir matematis. Pada fase entry, Scaffolding yang diberikan adalah explaining dengan menjelaskan maksud dari soal dan meminta S3 untuk mengidentifikasi gambar dan menuliskan hal-hal yang diketahui dan ditanyakan dengan benar. Memasuki fase attack, scaffolding yang diberikan adalah explaining, reviewing, and restructuring dengan meminta subjek untuk mengaitkan informasi yang diketahui dan ditanya. Memberikan pertanyaanpertanyaan kepada S3 untuk mengingat rumus phyatogas dengan menyederhanakan sketsa pada soal. Selanjutnya mengingatkan S3 dengan materi skala dan membantu S3 untuk menggunakan konsep skala untuk menyelesaikan soal. Kemudian membiarkan S3 untuk melanjutkan mengerjakan hingga menyimpulkan jawaban.

Pada fase review, scaffolding yang diberikan adalah meminta S3 untuk memeriksa perhitungan dan merefleksi langkah-langkah penyelesaian. Scaffolding berupa developing conteptual thingking juga diberikan dengan cara memberikan S3 waktu untuk memikirkan cara lain dan meminta S3 menyelesaikan masalah yang sama ketika beberapa item yang diketahui diubah, namun S3 tidak berhasil menemukan cara lain dan tidak bisa menyelesaikan soal jika hal yang diketahui diubah. Hal ini dikarenakan karena S3 belum lancar mengoperasikan bilangan bulat dan pecahan. Sehingga perlu diberikan beberapa bantuan dalam mengoperasikan bulat.

Pada fase entry, S3 membutuhhkan beberapa bantuan. Scaffolding yang diberikan adalah explaining dengan meminta subjek untuk membaca ulang soal dengan teliti, membacakan ulang soal dengan memberikan penekanan pada informasi-informasi yang penting dan meminta S3 untuk menuliskan hal-hal yang diketahui dan yang ditanyakan. Memasuki fase attack, scaffolding yang diberikan adalah memberikan pertanyaan-pertanyaan untuk membimbing S3 menemukan konsep kecepatan dengan cara mengaitkan dengan kehidupan sehari-hari. Selanjutnya mengingatkan S3 cara untuk mengubah satuan dari suatu besaran. Setelah S3 mengetahui rumus kecepatan, scaffolding yang diberikan adalah mengingatkan S3 tenatng kecepatan rata-rata. Kemudian membiarkan S3 untuk menyelesaikan soal dengan diberi peringatan jika melakukan kesalahan perhitungan.

Pada fase review, scaffolding yang diberikan adalah meminta S3 untuk meneliti kembali jawabannya dengan cara memeriksa perhitungan dan merefleksi langkahlangkah penyelesaian. Scaffolding berupa developing conteptual thingking juga diberikan dengan cara memberikan S3 waktu untuk memikirkan cara lain dan meminta S3 menyelesaikan masalah yang sama ketika beberapa item yang diketahui diubah.

Berdasarkan paparan tersebut, terdapat persamaan dan perbedaan proses berpikir matematis ketiga subjek. Ketiga subjek memulai proses berpikir matematis dengan membaca soal dan mengidentifikasi hal-hal yang diketahui dan hal yang ditanyakan. Akan tetapi, subjek berkemampuan matematika rendah tidak bisa menentukan 
informasi yang diketahui dengan benar. Ketiga subjek juga membuat dugaan-dugaan penyelesaian untuk menyelesaikan soal. Perbedaannya, subjek berkemampuan matematika tinggi mampu membuat dugaan-dugaan penyelesaian dan menyelesaikan soal nomor 1 dan 2 dengan benar, subjek berkemampuan matematika sedang membuat dugaan dan menyelesaikan soal nomor 1 dengan benar, sedangkan subjek berkemampuan rendah tidak dapat mengubah dugaan salah menjadi benar sehingga subjek belum dapat menyelesiakan semua soal dengan benar. Proses berpikir matematis subjek berkemampuan tinggi mengalami fase review, sedangkan subjek berkemampuan sedang dan rendah tidak mengalami fase review.

Berdasarkan hasil jawaban ketiga subjek. Ada 2 subjek yang dapat menyelesaikan soal nomor 1 dengan benar yaitu subjek berkemampuan matematika tinggi dan subjek berkemampuan matematika sedang. Ada 1 subjek yang dapat menyelesaikan soal nomor 2 yaitu subjek berkemampuan tinggi. Tidak ada subjek yang dapat menyelesaikan soal nomor 3 dengan benar. Hal ini tentu dipengaruhi oleh level soal PISA. Soal nomor 1 dan 2 adalah soal PISA level 5, sedangkan soal nomor 3 adalah soal PISA level 6.

Dengan memenuhi fase-fase berpikir matematis maka subjek akan semakin mudah dalam menyelesaikan soal. Jika dalam proses berpikirnya subjek dapat memenuhi fase berpikir matematis maka subjek akan mudah dalam menyelesaiakan soal PISA kategori HOTS. Hal ini sejalan dengan pendapat Kesumawati (2014), cara berpikir matematis adalah cara terbaik untuk menyelesaikan masalah matematika.

Scaffolding berperan penting untuk memenuhi fase berpikir matematis yang belum dipenuhi oleh subjek. Berdasarkan hasil tes dan scaffolding, subjek berkemampuan matematika tinggi belum bisa menyelesaikan soal PISA nomor 3, subjek berkemampuan matematika sedang belum dapat menyelesaikan soal PISA nomor 2 dan 3. Subjek berkemampuan matematika rendah tidak dapat menyelesaikan semua soal PISA. Setelah pemberian scaffolding subjek berkemampuan matematika tinggi, sedang maupun rendah dapat menyelesaikan soal dengan benar. Hal didukung dengan pendapat Wibowo dan Setianingsih (2016) yang mengatakan bahwa scaffolding dapat membantu siswa untuk mengembangkan proses berpikirnya.

Pemberian scaffolding kepada subjek berbeda-beda disesuaikan dengan kemampuan subjek. Ketika subjek sudah mampu memnyelesaikan soal maka pemberian scaffolding dihentikan. Hal ini sejalan dengan pendapat Murdiyani (2013) yang menyatakan bahwa saat menyelesaikan soal awalnya guru memberikan bantuan jika siswa megalami kesulitan dalam menyelesaikan masalah dan guru berhenti memberi bantuan kepada siswa dan memberikan kesempatan untuk menyelesaikan masalah dengan mandiri.

Scaffolding yang paling banyak diberikan kepada ketiga subjek adalah pada fase attack. Hal ini dikarenakan pada fase ini subjek diharuskan untuk membuat dugaan atau rencana penyelesaian sekaligus melaksanakan rencana tersebut untuk menyelesaikan masalah yang ada. Pada fase ini ini terdapat istilah stuck dan aha!. Stuck maksudnya siswa mengalami kendala saat berpikir atau siswa tidak dapat menyelesaikan soal. aha! ialah saat siswa menemukan ide untuk melanjutkan penyelesaian soal (Mason, dkk., 2010). Pada saat stuck inilah siswa memerlukan adanya scaffolding untuk membantu siswa menemukan aha!. Selain itu, syarat utama dalam menjalani fase ini adalah pengetahuan, teknik, prinsip dan konsep matematika, sehingga jika siswa kurang dalam memenuhi syarat tersebut siswa akan kesulitan untuk menyelesaikan masalah yang diberikan.

\section{PENUTUP}

\section{Simpulan}

Berdasarkan hasil penelitian dan pembahasan yang diperoleh, dapat disimpulkan bahwa (1) Proses berpikir matematis subjek berkemampuan tinggi dalam menyelesaikan soal PISA HOTS level 5 dimulai dengan fase entry, dengan memenuhi indikator know, want, dan introduce. kemudian proses dilanjutkan dengan fase attack dengan memenuhi aspek try, maybe, dan why. Kemudian dilanjutkan dengan fase review dengan memenuhi aspek check, reflect, dan extand. Proses berpikir matematis siswa berkemampuan matematika tinggi dalam menyelesaikan soal PISA HOTS level 6 dimulai dengan fase entry dengan melalui aspek know, want, dan introduce, dilanjutkan dengan fase attack dengan melalui aspek try dan maybe kemudian fase review dengan memenuhi aspek check, reflect, dan extand dan berulang dengan fase attack. Proses (2) Dalam menyelesaikan soal PISA HOTS proses berpikir matematis subjek berkemampuan sedang dimulai dengan fase entry melalui aspek know, want, dan introduce, dilanjutkan dengan fase attack dengan melalui aspek try, maybe, dan why. Siswa berkemampuan sedang tidak mengalami fase review karena tidak memenuhi semua indikator pada aspek fase review. (3) Proses berpikir matematis siswa berkemampuan matematika rendah dalam menyelesaikan soal PISA HOTS dimulai pada fase entry dengan memenuhi aspek know dan want. Kemudian dilanjutkan dengan memasuksi fase attack, namun hanya memenuhi aspek try. Pada fase attack, siswa berkemampuan matematika rendah memberikan dugaan penyelesaian, namun tidak memiliki alasan yang logis pada setiap dugaan penyelesaian yang dibuat. (4) Subjek 
berkemampuan matematika tinggi membutuhkan sedikit bantuan dalam menyelesaikan soal PISA HOTS level 6 pada fase attack. (5) Subjek berkemampuan matematika sedang membutuhkan scaffolding pada fase attack dan review. (6) Subjek berkemampuan matematika rendah membutuhkan scaffolding pada fase entry, attack dan review. (7) Setelah pemberian scaffolding, subjek berkemampuan tinggi, sedang maupun rendah memenuhi semua fase berpikir matematis. Sehingga subjek dapat menyelesaikan soal PISA kategori HOTS dengan benar.

\section{Saran}

Berdasarkan hasil penelitian dan simpulan yang telah diperoleh, kesulitan terbesar siswa siswa terletak pada fase attack. Hal ini dikarenakan siswa tidak bisa mengaitkan konsep yang dimilikinya. Oleh karena itu diperlukan penelitian yang lebih mendalam tentang kekurangan siswa dalam mengaitkan konsep yang dimilikinya dan cara untuk membantu siswa tersebut. Subjek penelitian ini hanya ditinjau dari kemampuan matematika siswa, oleh karena itu perlu adanya penelitian serupa dengan tinjauan yang berbeda.

\section{DAFTAR PUSTAKA}

Anghileri, Julia. 2006. "Scaffolding Practices That Enhace Mathematics Learning". Journal Of Mathematics Teacher Education. Vol. 9: hal. 33-52.

Astriyani, Arlin. 2019. “Analisis Proses Berpikir Matematis Peserta Didik dalam Menyelesaikan Masalah Aplikasi Turunan". Jurnal Pendidikan Surya Edukasi (JPSE). Vol. 5(2): hal. 135-143.

Daya, L., Lambertus, dan Sudia, M. 2017. "Proses Berpikir Siswa SMA dalam Memecahkan Masalah Matematik dengan Scaffolding Ditinjau dari Perbedaan Gaya Kognitif dan Gender”. Jurnal Pembelajaran Berpikir Matematika. Vol. 2(1): hal. 13-22.

Fatimah, Siti, Muhsetyo, G., dan Rahardjo, S. 2019. "Proses Berpikir Tingkat Tinggi Siswa SMP dalam Menyelesaikan Soal PISA dan Scaffoldingnya". Jurnal Kajian Pembelajaran Matematika. Vol. 3(1): hal. 24-33

Isroil, A., Budayasa, I. K., dan Masriyah. 2017. "Profil Berpikir siswa SMP dalam Menyelesaikan Masalah Matematika Ditinjau dari Kemampuan Matematika”. Jurnal Review Pembelajaran Matematika. Vol. 2(2): hal. 93-105.

Jo An, Yun dan Cao, Li. 2014. "Examining the Effects of Metacognitive Scaffolding on Students's Design
Probelm Solving and Metakognitive Skills in an Online Enviromental". Merlot Journal of Online Learning And Teaching. Vol. 10(4): hal 552- 568.

Kesumawati, Nila. 2014. "Kreativitas Berpikir Matematis dalam Pembelajaran Berkarakter". Delta-Pi: Jurnal Matematika dan Pendidikan Matematika. Vol. 3(1): hal. 1-10.

Mason, J., Burton, L., dan Stacey, K. 2010. Thinking Mathematically (Second Edition). Harlow: Pearson Education Limited.

Murdiyani, Nila Mareta. 2013. Scaffolding to Support Better Achievement in Mathematics. PHYTAGORAS: Jurnal Pendidikan Matematika. Vol. 8(1): hal.84-91.

OECD 2015. PISA 2015. Draft Mathematics Framework. (online), (Www.Oecd.Org, dikases 15 Maret 2020)

Retnodari, W., Elbas, W. F., dan Loviana, S. 2020. "Scaffolding dalam Pembelajaran Matematika". LINEAR: Journal of Mathematics Education. Vol. 1(1): hal. 15-21.

Setiawan, H., Dafik, Lestari, N. D. S. 2014. "Soal Matematika dalam PISA Kaitannya dengan Literasi Matematika dan Keterampilan Berpikir Tingkat Tinggi”. Prosiding Seminar Nasional Matematika, Jember, 19 November.

Tasdan, Tataroglu, Dkk. 2015. “A Daunting Task for PreService Mathematics Teachers: Developing Students' Mathematical Thinking". Educational Research And Review. Vol 10(6): Hal 2276-2289

Wardhani, W. A., Subanji, dan Dwiyana. 2016. "Proses Berpikir Siswa Berdasarkan Kerangka Kerja Mason". Jurnal Pendidikan: Teori, Penelitian dan Pengembangan. Vol. 1(2): hal. 297-313.

Wibowo, Pamujiarso Eko Hidayat dan Setianingsih, Rini. 2016. "Pemberian Scaffolding untuk Meningkatkan Keterampilan Berpikir Tingkat Tinggi (Higher Order Thinking Skills) Kelas X SMA berdasarkan Kemampuan Matematika Siswa. MATHEdunesa: Jurnal Ilmiah Pendidikan Matematika. Vol. 2(5): hal. 73-80.

Yani, M., M, Ikhsan, dan Marwan. 2016. "Proses Berpikir Siswa Sekolah Menengah Pertama dalam Memecahkan Masalah Matematika Berdasarkan Langkah-Langkah Polya Ditinjau dari Adversity Quotient”. Jurnal Pendidikan Matematika. Vol. 10(1): hal 43-57 